\section{SOI: 1.1/TAS DOI: 10.15863/TAS International Scientific Journal Theoretical \& Applied Science}

p-ISSN: 2308-4944 (print)

e-ISSN: 2409-0085 (online)

Year: 2015

Issue: 11

Volume: 3

Published: 30.11.2015 http://T-Science.org

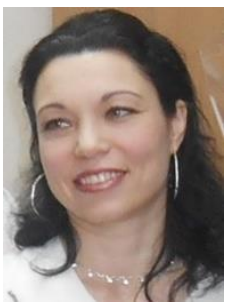

Tetiana P. Golub

$\mathrm{PhD}$, associate professor, National Technical University of Ukraine,

"Kyiv Polytechnic Institute", Ukraine ukraine.golub@gmail.com

SECTION 5. Innovative technologies in science.

\title{
GLOBAL PROMOTION OF INNOVATIVE SUSTAINABLE DEVELOPMENT
}

\begin{abstract}
The article is devoted to the study and analysis of the concepts 'sustainable development' and 'sustainable innovative development', the study of organizations that devoted their activities to the problems of sustainable development, the main principles of innovative development and the importance of innovative development for modern enterprises.

Key words: innovations, sustainable development, management, organizations, enterprise.

Language: English

Citation: Golub TP (2015) GLOBAL PROMOTION OF INNOVATIVE SUSTAINABLE DEVELOPMENT. ISJ Theoretical \& Applied Science 11 (31): 82-86.
\end{abstract}

Soi: http://s-o-i.org/1.1/TAS-11-31-14 Doi: crossef http://dx.doi.org/10.15863/TAS.2015.11.31.14

The global world is moving up to the sustainable mode of its development, ensuring the preservation of society and environment development, and protection from natural and artificial social, economic and ecological crises in the conditions of negative internal and external influences.

The concept "sustainable development" was introduced into global politics in 1987 , when the $42^{\text {nd }}$ session of the UN General Assembly had adopted the "Basic principles of sustainable development" [1, p. 43], which includes two groups of concepts: the possibility and needs for conservation and development of systems of any nature and for any purpose. It is targeted in preservation of growth opportunities to meet nonvanishing needs at the expence of changes in technology perfection and planning quality factors, that characterize the presence of unmet needs rather than consumer demand.

The concept "sustainable innovative development" is defined as a process of growth of the system's useful output due to the innovations implementation, that ensure non-decreasing growth rate of the total power efficiency (resources) and the income, reduction of losses due to negative external and internal influences [2].

Nowadays in conditions of global crisis (financial, economic, social) it seems that we can only dream about sustainable development. But crisis is the time of renewal. Right now it is necessary not only to look for ways out of the crisis, but to develop the plans of transition to sustainable growing mode of economic and social development as well. To evaluate its advance it is necessary to develop a set of measures based on objective, measurable terms that can depict deviations from the predetermined direction.

It is important to develop the methods of sustainable development management, that provide introduction of new technologies without slumps at the end of recessions of their explosive potential. It is necessary to create mathematical models, information technologies that manage sustainable development, ensuring social stability so that no change in external conditions of the global economy, no innovation and technological revolution, could destroy the way of life of millions of people. Thus, the scientific methods of sustainable development elaboration, of transition to such mechanism of social and economic functioning should be complemented by methods of state control in a stable environment of constant growth.

These areas of scientific research are really topical. The issue of sustainable development has become a subject of theoretical and applied research, it is actively discussed in scientific works, at national and international conferences. Political, environmental, organizational, financial and economic aspects of sustainable development are the topic of many works of scientists. However, there are only few studies in which theoretical and 
methodological foundations of these aspects are interrelated in a full picture on the basis of general laws of nature in terms of universal systemic measures.

Scientists around the world are in touch with each other. However, the acceleration of the rhythm of life, science and economy requires an increase in the intensity of scientific communication. For this it is necessary to accelerate the process of introducing new ideas, methods and technologies, especially in those areas that are related to sustainable development into scientific circulation [3].

States are actively developing crisismanagement, security, growth and sustainable development strategies. The scientific centers that perform fundamental and applied research problems of transition to sustainable development, and develop appropriate action programs are established. Sustainable development oriented organizations include international organizations, NGOs, institutes, business organizations, and foundations. Among them are:

- World Resources Institute (WRI), USA [4]. WRI's mission is to move human society to live in ways that protect Earth's environment and its capacity to provide for the needs and aspirations of current and future generations. WRI organizes its work around six critical goals that the world must achieve this decade in order to secure a sustainable future:

1. Climate: protect communities and natural ecosystems from damage caused by greenhouse gas emissions, and generate opportunities for people by catalyzing a global transition to a low-carbon economy.

2. Energy: drive the scale-up of clean, affordable power systems throughout the world to deliver sustainable socio-economic development.

3. Food: ensure the world's food systems reduce their impact on the environment, drive economic opportunity, and sustainably feed 9.6 billion people by 2050 .

4. Forests: alleviate poverty, enhance food security, conserve biodiversity, and mitigate climate change by reducing forest loss and restoring productivity to degraded, deforested lands.

5. Water: achieve a water-secure future by mapping, measuring, and mitigating global water risks.

6. Cities and Transport: improve quality of life in cities by developing and scaling environmentally, socially, and economically sustainable urban and transport solutions.

- Worldwatch Institute [5], USA is an independent research institute devoted to global environmental concerns. Woldwatch develops innovative solutions to intractable problems, emphasizing a blend of government leadership, private sector enterprise, and citizen action that can make a sustainable future a reality.

- International Institute for Sustainable Development [6], Canada - IISD's mission is to promote human development and environmental sustainability through innovative research, communication and partnerships. The institute has offices in Canada, Switzerland and the United States, and operates in over 70 countries around the world. 2014-2019 Strategic Plan builds upon IISD's core strengths in advancing integrated, multidisciplinary and leading-edge perspectives and real-world solutions to sustainability. The strategy consolidates different IISD work streams in a focused and integrated manner. A core purpose of the strategy is to build a single, coherent institution capable of providing integrated and holistic solutions to sustainability challenges;

- The Research Council of Norway [7], Norway - supports the practical activities in the field of sustainable development.

- International Academy of the Environmental Sciences [8] is a nonprofit and registered international organization. It devotes to promote global ecology and environmental sciences and protect global ecological environments, by publishing scientific publications, conducting research activities, launching environmental programs, disseminating knowledge and technologies, sponsoring conferences, and providing information and discussion spaces, etc.

- The International Centre for Research in Ecological Economics, Eco-Innovation and Tool Development for Sustainability (REEDS) [9] is a centre at the Université de Versailles Saint-Quentinen-Yvelines, France, led by Professor Martin O'Connor, one of Europe's best-known ecological economists. At the present, the centre involves about 50 researchers. REEDS gives advice on policy at French, European and international levels and in corporate social responsibility. It is strong in research in African countries. It is particularly strong in the methodologies of integrated economic-environmental analysis, quantitative economic analyis, GIS and spatial analysis, risk assessment, interactive multimedia techniques (platform KerBabelTM), multicriteria multi-actor analysis and participatory action research.

- Sustainable Europe Research Institute SERI Germany e.V. [10] . The Sustainable Europe Research Institute (SERI) is a Pan-European think tank exploring sustainable development options for European societies and the European impact on global sustainable development. It was set up in September 1999, and the German institute SERI Germany e.V. was founded in 2005. For more than 10 years, SERI Germany has been active in the field of sustainability assessments, for research projects, governments and business. The core of SERI 
Germany's work consists of European and member state research projects towards sustainability strategies, evaluation, monitoring and indicators, and on sustainable consumption. Recent activities include projects like ALARM, a major biodiversity research project, SuStrat, a project to identify best practice in sustainability strategy development and derive suggestions for EU policies, or SCORE, a major policy analysis project in the field of sustainable consumption. SERI policy related work includes participation in the peer review of the Dutch national sustainability strategy, or the coaching of the Luxembourg government in the process of developing and monitoring a new national sustainability strategy. While its core competence is in economics (empirical and ecological economics), SERI Germany analyses cover social, institutional and environmental factors as well. Thus SERI integrates the ecological objective to reduce environmental space use/respecting planetary boundaries with elaborated economic, social and institutional sustainability analyses and strategies to sustainably shape the safe operating space of humankind. SERI develops strategies on the macro, meso, micro and meta levels of economies and societies focussing on the notion of environmental space (in terms of material flow analysis, energy systems and land--use analysis) and the measurability of social and economic dimensions of sustainable development. SERI looks at the impact of activities and policies in Europe on other parts of the world.

$$
\text { - at al. }
$$

Dr. Juhász Csaba and Szőllősi Nikolett at their work "Environmental management" [11] indicate the basic principles of sustainable development that make possible to harmonise the various sectoral and development strategies with the horizontal strategy on sustainable development and also provide a general type of guidance for determining the Strategy's priorities, more specifically defined goals and tasks, the frameworks and means of implementation, in a coordinated and harmonised way. The basic principles have been formulated, clarified, and adopted at the highest levels by the relevant bodies of both the UN and the EU. On account of their national relevance the following 10 should be highlighted from the complete set of principles:

1. The principle of holistic approach. Things must be viewed as a system of interrelated elements, the elements themselves also being systems interacting with one another. Any intervention may trigger ripple effects even in remote systems. So local challenges can be adequately addressed relying on the knowledge of the wider environment and global trends alike.
2. The principle of intragenerational and intergenerational solidarity. The interests of sustainable development are focused on people. The development and environmental needs of present generations must be addressed without compromising the ability of future generations to meet their own needs.

3. The principle of social justice. The right to adequate conditions for living must be recognised and fundamental human rights must be guaranteed for all. All people should have equal opportunities for acquiring knowledge and skills required to become worthy members of society.

4. The principle of sustainable management of resources. Sustainable management of resources with a view to the limitations of the carrying capacity of the environment; by using natural resources in a prudent and thrifty way it preserves resources required for future development.

5. The principle of integration. In the course of elaborating, evaluating, and implementing sectoral policies, plans, and programmes, economic, social, and environmental considerations and their relationships must also be taken into account to ensure that they can mutually reinforce each other.

6. The principle of utilising local resources. Efforts should be made to supply the needs of communities on a local level, from local resources. Local features and diversity should be preserved. Preservation and sustainable utilisation of the manmade environment and cultural heritage are also very important tasks.

7. The principle of public participation. Adequate access to information affecting social/economic life and the environment, to information on decision making processes must be provided for all. People's knowledge about sustainable development, its social/economic and environmental implications, and about sustainable solutions and approaches must be clarified and enhanced. Public participation in decision making should be strengthened.

8. The principle of social responsibility. To enable sustainable development and to make a higher quality of life possible, unsustainable patterns of production and consumption must be changed. Businesses' social responsibility must be strengthened, along with cooperation between the private and the public sector.

9. The principle of precaution and prevention. The precautionary approach means that wherever the possibility of severe or irreversible damage is perceived, a lack of complete scientific certainty may not be used as an excuse for delaying effective action to prevent damage to the environment or endangering human health; i.e. action must be taken in view of the gravity of the perceived threat. Human activities must be planned 
and carried out in line with this precautionary principle and activities damaging or polluting the environment endangering natural systems and human health must be prevented and - where it is not possible - reduced, and finally, damages must be restored to their original state as far as possible.

10. The polluter pays principle. Prices must reflect the real costs paid by society for activities involved in consumption and production as well as for their impacts, including the costs of using natural resources. Those engaged in activities damaging/polluting the environment must pay for damage caused to human health or the environment.

Sustainable Innovative Development is one of the components of national economy of most of word countries. Nowadays, there is no country in the world where competition for leadership in the global markets is not associated with innovation. This is due to many factors: depreciation of fixed production assets, high cost price, and as a consequence - a low competitiveness of goods on domestic and foreign market.

Currently, many enterprises are operating in the conditions of negative phenomena, both objective and subjective. These phenomena significantly affect the susceptibility of enterprises to market requirements related to the innovative development of economic entities and, therefore, the effect occurs in the stable position, competitiveness. At the present stage of market relations development there is a need to use new approaches to the sustainable innovative development of enterprises.

The introduction of innovations in enterprises leads to a renewal of the range of manufactured products, rise of product quality to meet consumer demand and profit maximization, therefore, is an increase in the effectiveness of the entity.

However, to achieve sustainable innovative development of enterprises it is necessary to provide the potential for growth and the potential for further development. As a rule, this potential is a profit. A business entity may develop in different directions:

1. Extensive development. It is due to the increase in production and sales, carried out under the conditions of an unsaturated market when there is no intense competition, relatively stable environment management. This path involves an increase in cost of resources;

2. Intensive development. It involves the use of science and technology to improve the design and technology of traditional goods production. This will reduce the cost of production, improve quality, therefore, improve the competitiveness of products;

3. Innovative development. It is associated with a continuous updating of the range of products and technology of its production, improving production management system and marketing.

The main task of any company is to maintain own competitiveness as long as possible and provide a level of financial and economic indicators not lower than the average. This will enable businesses to form strategic stability and as a result to develop and maintain long-term competitive advantages, providing high quality products and the demand for it. The main advantage of the company in this case is innovation.

In modern conditions of economic development the managers of different levels face a problem of reformatting systems, methods, techniques and economic mechanisms of sustainable development management in terms of innovation. This is one of the most important and decisive conditions for overcoming the crisis, as an active innovative activity provides strategic stability of an enterprise.

Many international scientists treat innovation as a means of scientific discovery, technological invention implementation in the form of new products, new technology to meet the needs of society. This is reflected in the emergence of new means of production, new products, technologies, that bring additional revenue. In the broadest sense innovation are the procedures and the means by which scientific discoveries are implemented in the social and economic novations. It should be noted that the innovative approach is a systematic process of qualitative changes of products, means of labor, objects of labor, technology, production and management. The aim of this process is to improve the competitiveness and production efficiency.

The innovative approach allows business entity to give the status of innovative sustainability and classify it as an innovative sustainable business.

Innovative development of an enterprise involves improving the quality of products, efficient use of resources, improved labor productivity on the basis of the qualitative changes in technology, organization and management of the production process to ensure a profit. The second area of enterprise development, mainly sustainability is based on the principles, methods that promote technological, financial and organizational sustainability of an enterprise. Together, they provide innovative sustainability of an enterprise and are based on a permanent activation of innovation.

It should be noted that the effectiveness of the innovative development of an enterprise is determined by the ratio of organization profit and spendings.

There are four types of the effect of innovations:
1) economical;
2) resource;
3) technical;
4) social.

The successful implementation of innovation in an enterprise is also influenced by such factors as: production and technical base, investment, scientific and technical progress, control system, main types of 


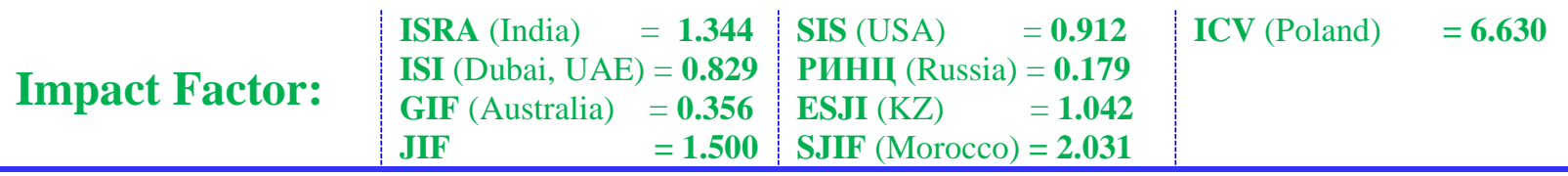

resources. Proper ratio and the operation of these factors lead to a positive result in innovation strategy implementation.

An important point in the strategic planning of innovation is the account of the innovation potential competitors and the attitude of state bodies to the innovative development of an enterprise, as well as the situation in the country as a whole.

Innovative development of an enterprise is a process of focused, consistent movement of the enterprise to a balanced innovative state under the influence of various external and internal factors that determine the sustainability of the organizational and functional management system in the context of globalization, which is characterized by the result of the quality achieved, depending on the intensity and rate of the enterprise innovation processes.

Thus, if an enterprise reorients for innovative sustainability, it will lead to more efficient production and, therefore, ensure the output of the economy from the crisis.

\section{References:}

1. (1987) United Nations General Assembly. Report of the world commission on environment and development: Our common future. Oslo, Norway: United Nations General Assembly, Development and International Co-operation: Environment.

2. (2015) Electronic atlas of the parameters of sustainable innovative development. Available: http://lt-gis.ru/ (Accessed: 10.11.2015).

3. (2015) Sustainable innovative development: design and management. Electronic scientific journal. Available: http://www.rypravlenie.ru/ (Accessed: 10.11.2015).

4. (2015) World Resources Institute. Available: http://www.wri.org/ (Accessed: 10.11.2015)

5. (2015) Worldwatch Institute. Available: www.worldwatch.org/

(Accessed: 10.11.2015)

6. (2015) International Institute for Sustainable Development. Available: www.iisd.org/ (Accessed: 10.11.2015).
7. (2015) The Research Council of Norway. Available: http://www.forskningsradet.no/ (Accessed: 10.11.2015).

8. (2015) International Academy of the Environmental Sciences. Available: http://www.iaees.org/ (Accessed: 10.11.2015)

9. (2015) The International Centre for Research in Ecological Economics, EcoInnovation and Tool Development for Sustainability. Available: http://www.ejolt.org/2011/09/reeds/ (Accessed: 10.11.2015).

10. (2015) Sustainable Europe Research Institute SERI Germany. Available: http://www.seri.de/ (Accessed: 10.11.2015).

11. (2015) Dr. Juhász Csaba, Szőllősi Nikolett (2008) Environmental management. Available:

http://www.tankonyvtar.hu/en/tartalom/tam op425/0032_kornyezetiranyitas_es_minose gbiztositas/ch04s02.html (Accessed: 10.11.2015) 